JKM (Jurnal Kebidanan Malahayati),Vol 7,No.3.Juli 2021,

ISSN (Print) 2476-8944 ISSN (Online) 2579-762X, Hal 523-527

\title{
PEMBERIAN AIR REBUSAN DAUN MINT UNTUK MENGURANGI MUAL MUNTAH PADA IBU HAMIL TRIMESTER I
}

\author{
Yusmaharani ${ }^{*}$, Nurmaliza ${ }^{2}$, Rini Hariani Ratih ${ }^{3}$ \\ 1,2,3fakultas Farmasi dan IImu Kesehatan Universitas Abdurrab Pekanbaru Riau I \\ *Korespondensi email yusmaharani@univrab.ac.id
}

\begin{abstract}
GIVING MINT LEAVES STEW TO REDUCE NAUSEA AND VOMITING IN 1ST TRIMESTER PREGNANT WOMEN
\end{abstract}

Background : Pregnancy can cause changes in the overall condition of a woman's body such as physical, psychological and hormonal changes, hormonal changes that occur in pregnant women due to an imbalance in the work of the hormones estrogen and progesterone. This imbalance results in placental HCG or (Human Chorionic Gonadotropine). This can cause nausea and vomiting in pregnant women or is called emesis gravidarum. Pregnant women who experience nausea and vomiting can experience complications in about 60$80 \%$ in primigravida and around $40-60 \%$ in multigravida. Mint leaves are known to be a safe and effective medicine for treating nausea and vomiting in pregnant women. Attrition oil content in mint leaves is useful for smooth digestive system and overcome spasms that sometimes occur in the stomach. such as muscle spasms in the process of nausea and vomiting. Mint leaves can be drunk in tea, or eaten like candy.

Purpose: To find out the effect of giving mint leav stew to reduce nausea and vomiting in trimester 1 pregnant women at the Jambu Mawar Primary Clinic.

Methode : The study used a pre-experimental research design that was one group pretest-posttest. The sample in this study were pregnant women in the first trimester at the Jambu Mawar Primary Clinic Pekanbaru, taken by purposive sampling of 32 people. Bivariate analysis used paired t-test to see the effect of giving drinks. Mint leaves against nausea and vomiting of mothers in the first trimester. The questionnaire used for data collection contains general data, the frequency of nausea and vomiting before and after the intervention was given.

Result : The results of the study found that the majority of respondents were in the age of 20 - 30 years, as many as 18 people (59.3\%). Based on the parity variable, the majority of multigravida were 21 people (65.6\%). Based on the work variable, the majority of housewives or not working as many as 25 people (78.1\%). The effect of giving mint leaf boiled water on nausea and vomiting, before being given the intervention the average respondent experienced nausea and vomiting 7 times a day, after being given the mint leaf boiled water intervention the average frequency of nausea and vomiting decreased to 3.8 times a day with $P$ value $=0.000$. The results of this study can be concluded that both clinically and statistically, mint leaf boiled water has an effect on reducing the frequency of nausea and vomiting in first trimester pregnant women.

Conclusion: There is an effect on the frequency of nausea and vomiting in pregnant women in the first trimester at the Primary Jambu Mawar clinic with a value of Pvalue $=0,000$. Researcher's hope for respondents is that they can add insight to respondents about how to reduce nausea and vomiting in early pregnancy using mint leaf drinks.

Suggestion It is recommended for health workers to use the results of this study as an alternative to overcome nausea and vomiting in pregnant women. Respondents, namely pregnant women, can apply a decoction of mint leaves to treat nausea and vomiting during pregnancy.

Keywords : Mint leaf Stew Water, Neasusea, Vomiting, 1st Trimaster or Pregnancy

\section{ABSTRAK}

Latar Belakang : Kehamilan dapat menyebabakan perubahan kondisi tubuh perempuan secara keseluruhan seperti perubahan fisik, psikis dan hormonal, perubahan hormonal yang terjadi pada perempuan hamil karena ketidakseimbangan kerja hormon estrogen dan progestrogen. ketidakseimbangan ini menghasilkan HCG plasenta atau (Human Chorionic Gonadotropine). Hal ini dapat menyebabkan rasa mual dan muntah pada ibu hamil atau disebut dengan emesis gravidarum. Ibu hamil yang mengalami mual dan muntah dapat terjadi komplikasi sekitar $60-80 \%$ terjadi pada primigravida dan sekitar $40-60 \%$ pada multigravida. Daun mint diketahui bisa menjadi obat yang aman dan efektif untuk mengobati mual dan muntah pada lbu Hamil. Kandungan minyak 
atrisi pada daun mint berguna untuk kelancaran sistem pencernaan serta mengatasi kejang yang kadang terjadi pada perut. seperti kejang otot pada proses mual dan muntah. Daun mint bisa diminum di jadikan teh, atau pun dimakan seperti perment.

Tujuan : Untuk mengetahui pengaruh pemberian air rebusan daun mint untuk mengurangi mual muntah pada ibu hamil Trimester 1 di Klinik Pratama Jambu Mawar

Metode : Penelitian menggunakan design penelitian Pra-eksperimen yang bersifat one grup pretestpostest Sampel pada penelitian ini adalah ibu hamil trimester I di Klinik Pratama Jambu Mawar Pekanbaru di ambil secara purposive sampling sebanyak 32 orang Analisis bivariat menggunakan uji paired t-test untuk melihat pengaruh pemberian air rebusan daun mint terhadap mual muntah ibu trimester I. Kueioner yang digunakan untuk pengumpulan data berisi tentang data umum, frekuensi mual dan muntah sebelum dan setelah diberikan intervensi.

Hasil : Hasil penelitian di dapatkan bahwa mayoritas responden berada pada umur 20 - 30 tahun yaitu sebanyak 18 orang (59,3\%). Berdasarkan variabel paritas mayoritas multigravida sebanyak 21 orang $(65,6 \%)$. Berdasarkan variable pekerjaan Mayoritas ibu rumah tangga atau tidak bekerja sebanyak 25 orang $(78,1 \%)$. Pengaruh pemberian air rebusan daun mint terhadap mual dan muntah, sebelum diberikan intervensi rata-rata responden mengalami mual dan muntah sebanyak 7 kali sehari, setelah diberikan intervensi air rebusan daun mint rata-rata frekuensi mual dan muntah menurun menjadi 3,8 kali dalam sehari dengan nilai Pvalue $=0,000$. Hasil penelitian ini dapat disimpulkan bahwa baik secara klinis maupun statistic, air rebusan daun mint memberikan pengaruh terhadap penurunan frekuensi mual dan muntah pada ibu hamil trimester I.

Kesimpulan : Terdapat pengaruh pemberian air rebusan daun mint terhadap frekuensi mual dan muntah pada ibu hamil trimester 1 di klinik Pratama Jambu Mawar dengan nilai Pvalue $=0,000$ dengan demikian daun mint mampu mengurangi frekuensi mual muntah pada ibu hamil Trimester I.

Saran bagi tenaga kesehatan dapat menjadikan hasil penelitian ini sebagai alternatif untuk mengatasi mual muntah pada ibu hamil. Bagi responden yaitu ibu hamil dapat mengaplikasikan rebusan daun mint untuk mengatasi mual muntah saat hamil.

Kata Kunci : Air Rebusan Daun Mint, Mual Muntah, Hamil Trimester 1

\section{PENDAHULUAN}

Kehamilan merupakan proses yang sangat di nantikan oleh keluarga, kehamilan dapat menyebabkan perubahan kondisi tubuh perempuan secara keseluruhan seperti perubahan fisik, psikis dan hormonal, perubahan hormonal yang terjadi pada perempuan hamil karena ketidakseimbangan kerja hormon estrogen dan progestrogen. ketidakseimbangan ini menghasilkan HCG plasenta atau (Human Chorionic Gonadotropine), Khususnya pada trimester awal kehamilan. Hal ini dapat menyebabkan rasa mual dan muntah pada ibu hamil atau disebut dengan emesis gravidarum. (Mandriwati, 2018;Smith, et al 2018)

Keluhan emesis gravidarum merupakan hal yang fisiologis, namun jika tidak segera diatasi akan menjadi berbahaya bagi ibu hamil. Mual muntah pada ibu hamil dapat menyebabkan cairan tubuh berkurang sehingga terjadi hemokonsentrasi yang dapat memperlambat peredaran darah, hal ini dapat mempengaruhi tumbuh kembang janin di dalam Rahim. Di Indonesia ibu hamil trimester pertama yang mengalami Mual muntah sebanyak 50\%-75\% (Wulandari, et.al. 2019)

Menurut WHO 2013 dari total seluruh kehamilan di Dunia terdapat 12,5\% jumlah kejadian hyperemesis gravidarum. Mual dan muntah ini dapat mengakibatkan ketidakesimbangan cairan dan dapat mengganggu oragan ginjal dan hati menjadi nekrosis. Ibu hamil yang mengalami mual dan muntah dapat terjadi komplikasi sekitar 60-80\% terjadi pada primigravida dan sekitar $40-60 \%$ pada multigravida (Manuaba et al., 2015).

Penelitian yang dilakukan Suwarni (2019) di dapatkan data sebanyak $50-90 \%$ rasa mual muncul pada trimester 1 kehamilan. $12 \%$ juga dialami ibu sampai melahirkan.Mual muntah pada ibu hamil ini dapat di obati menggunakan tanaman herbal salah satunya daun mint. Daun mint disebut juga dengan peppermint atau dikenal dengan nama ilmiah Mentha piperita $L$ merupakan sebuah tanaman herbal yang sangat terkenal di seluruh dunia. daun mint diketahui bisa menjadi obat yang aman dan efektif untuk mengobati mual dan muntah pada Ibu Hamil (Elshabrina, 2013).

Sebuah studi penelitian mengungkapkan daun mint dapat memperbaiki aliran empedu yang digunakan tubuh untuk mencerna lemak dan menenangkan otot perut, serta meringankan kejang perut. Dengan demikian rasa mual dan muntah yang timbul akibat kontraksi otot perut dapat di redakan menggunakan daun mint. Daun mint bisa 
diminum di jadikan teh, atau pun dimakan seperti perment. (Selina, et.al, 2019).

Studi lain dari Wheling Jesuit University, US, menyimpulkan bahwa kandungan minyak atrisi pada daun mint yaitu berupa kandungan mentol berguna untuk kelancaran sistem pencernaan serta mengatasi kejang yang kadang terjadi pada perut. seperti kejang otot pada proses mual dan muntah (Tiran D, 2018).

Berdasarkan studi pendahuluan yang dilakukan oleh peneliti kepada 10 orang ibu hamil trimester 1 yang berkunjung ke Klinik Pratama Jambu mawar Pekanbaru $70 \%$ mengalami mual muntah, diantaranya mengalami mual muntah pada pagi hari dengan frekuensi $4-5 x$ dalam sehari. 5 diantara ibu hamil tersebut mengatakan mengkonsumsi obat-obat tradisinal untuk mengurangi mual dan muntah, namun tidak satupun menggunakan daun mint untuk mengatasi mual muntahnya. Adapun tujuan dari penelitian ini adalah untuk mengetahui pengaruh pemberian air rebusan daun mint untuk mengurangi mual muntah pada ibu hamil Trimester 1 di Klinik Pratama Jambu Mawar

\section{METODOLOGI PENELITIAN}

Penelitian menggunakan design penelitian Pra-eksperimen yang bersifat one grup pretestpostest (Sugino, 2012) Sampel pada penelitian ini adalah ibu hamil trimester I di Klinik Pratama Jambu Mawar Pekanbaru di ambil secara purposive sampling sebanyak 32 orang dengan kriteria lbu hamil Trimester 1, mengalami mual dan muntah lebih dari $3 x$ sehari, tidak sedang mengkonsumsi obat-obatan anti mual. Analisis bivariat menggunakan uji paired t-test untuk melihat pengaruh pemberian air rebusan daun mint terhadap mual muntah ibu trimester I. Kueioner yang digunakan untuk pengumpulan data berisi tentang data umum, frekuensi mual dan muntah sebelum dan setelah diberikan intervensi.

\section{HASIL DAN PEMBAHASAN \\ Analisis Univariat}

Hasil penelitian di dapatkan bahwa mayoritas responden berada pada umur 20 - 30 tahun yaitu sebanyak 18 orang $(59,3 \%)$ umur $>30$ tahun sebanyak 14 orang $(43,7 \%)$. Berdasarkan variabel paritas mayoritas multigravida sebanyak 21 orang $(65,6 \%)$ dan primigravida sebanyak 11 orang $(34,4 \%)$. Berdasarkan variable pekerjaan Mayoritas ibu rumah tangga atau tidak bekerja sebanyak 25 orang $(78,1 \%)$ dan bekerja sebanyak 7 orang $(21,9 \%)$.

Tabel 1.

\section{Karekteristik Responden}

\begin{tabular}{lcc}
\hline \multicolumn{1}{c}{ Karakteristik } & N & $\%$ \\
\hline Umur : & & \\
20-30 Tahun & 18 & 59,3 \\
>30 Tahun & 14 & 43,7 \\
Paritas : & & \\
Primigravida & 11 & 65,5 \\
Multigravida & 21 & 34,4 \\
Pekerjaan : & & \\
Bekerja & 7 & 21,9 \\
IRT/Tidak Bekerja & 25 & 78,1 \\
\hline \multicolumn{1}{c}{ Total } & 32 & 100 \\
\hline \multicolumn{1}{c}{}
\end{tabular}

\section{Analilsis bivariat}

Pengaruh pemberian air rebusan daun mint terhadap mual dan muntah, sebelum diberikan intervensi rata-rata responden mengalami mual dan muntah sebanyak 7 kali sehari, setelah diberikan intervensi air rebusan daun mint rata-rata frekuensi mual dan muntah menurun menjadi 3,8 kali dalam sehari dengan nilai Pvalue $=0,000$. Hasil penelitian ini dapat disimpulkan bahwa baik secara klinis maupun statistic, air rebusan daun mint memberikan pengaruh terhadap penurunan frekuensi mual dan muntah pada ibu hamil trimester I.

Tabel 2.

Frekuensi Mual Muntah Sebelum dan setelah Pemberian Muniman Daun Mint

\begin{tabular}{ccccccc}
\hline Intervensi & Mean & $\mathrm{N}$ & $\begin{array}{c}\text { Mean } \\
\text { Perbedaan }\end{array}$ & SD & SE & Pvalue \\
\hline Sebelum & 7 & 32 & 3,8 & 0,000 & 0,000 & 0,000 \\
Sesudah & 3,2 & 32 & & 0,936 & 0,161 & 0 \\
\hline
\end{tabular}

\section{PEMBAHASAN}

Berdasarkan hasil penelitian di dapatkan bahwa rata-rata responden mengalami mual muntah sebelum intervensi sebanyak 7 kali sehari, setelah intervensi dengan mengkonsumsi air rebusan daun mint terdapat penurunan frekuensi mual muntah menjadi 3,2 kali sehari dengan nlai Pvalue $=0,000$. Hasil penelitian ini dapat disimpulkan bahwa air rebusan daun mint dapat memberikan pengaruh terhadap penurunan 
frekuensi mual dan muntah pada ibu hamil trimester I.

Peneiltian ini sesuai dengan penelitian yang dilakukan oleh afriyanti (2017) menunjukkan bahwa hasil uji t test penelitian mendapatkan angka rerata frekuensi muntah sebelum meminum daun mint 5,29 kali sehari dan setelah mengkonsumsi daun mint sebesar 3,57 kali sehari. Hasil uji menunjukkan terdapat pengaruh konsumsi daun mint terhadap frekuensi mual dan muntah ibu hamil trimester pertama dengan emesis gravidarum.

Hasil penelitian ini sesuai juga dengan penelitian yang dilakukan oleh Istogomah (2017) pemberian rutin seduhan daun peppermint dapat berpengaruh pada penurunan frekuensi mual dan muntah pada ibu hamil di BPM Ibu Salamah, Amd. Keb Desa Peterongan Kec. Peteronngan Kab. Jombang.. Dengan hasil uji statistik dengan menggunakan uji Paired T-Test dengan program SPSS 16.0 diperoleh Sig. (2-tailed): Nilai probabilitas $/ p$ value uji $T$ Paired: Hasil $=0,000$ dengan nilai $P$ value $<0,05$ Artinya ada perbedaan signifikan frekuensi mual muntah antara sebelum dan sesudah perlakuan pemberian seduhan daun peppermint pada ibu hamil. Nilai rata-rata adalah 2.600 bernilai positif, artinya terjadi kecenderungan penurunan frekuensi mual dan muntah pada ibu hamil sesudah perlakuan pemberian seduhan daun peppermint.

Penelitian ini sesuai dengan penelitian yang di lakukan Harahap, et.al, (2020) di dapatkan Hasil uji statistik dengan independent sample $t$ test diperoleh nilai $p$ 0,018<0,05 yang menunjukkan ada perbedaan efektivitas yang signifikan terhadap pengurangan emesis gravidarum baik pada kelompok intervensi teh daun mint dan control yang berarti terdapat pengurangan emesis gravidarum dengan menggunakan intervensi daun mint

Mual muntah muncul karena meningkatnya asam lambung dikarenakan adanya peningkatan kadar hormone estrogen pada awal kehamilan. Rasa mual ini akan timbul bisa dikarenakan kondisi perut yang kosong sehingga asam lambung meningkat serta di dukung oleh adanya hormone HCG. (Elshabrina, 2013).

Untuk mengatasi mual dan muntah pada masa kehamilian dapat dilakukan dengan terapi komplementer menggunakan tanaman herbal yaitu jahe, peppermint, lemon (Somoyani, 2018). Peppermint juga diketahui bisa menjadi obat yang aman dan efektif untuk mengobati mual muntah pada ibu hamil. Daun mint mengandung minyak atsiri yaitu menthol yang memiliki efek anastesi ringan untuk meringankan kejang perut atau kram. Daun mint juga memiliki efek karminatif dan antispasmodik yang bekerja di usus halus pada saluran gastrointestinal sehingga mampu mengatasi atau menghilangkan mual muntah dan memperlancar sistem pencernaan (Arumsari, 2019)

Daun mint terdiri dari air, serat, protein abu, dan karbohidrat. Kandungan mineral yang berlimpah seperti kalsium, kalilum, magnesium, mangn, natrium, fosfor, dan tembaga. Daun mint juga mengandung vitamin $A, B, C$ dan $D$ serta memiliki kandungn asam amino yang berlimpah. Daun mint memiliki minyak essensial yang dapat di ekstrak menjadi mentol. (Parwitasari, 2014)

Daun peppermint banyak mengandung minyak atsiril yaitu mentol yang dapat meringankan kembung, mual, muntah, kram dan mengandung efek karminative yang bekerja diusus halus pada saluran gastrointestinal sehingga mampu mengatasi/ menghilangkan mual muntah. (Ira, 2012).

Dari hasil penelitian di atas dapat di ketahui bahwa mayoritas responden mengalami perubahan frekuensi mual muntah setelah mengkonsumsi air rebusan daun mint. Hal ini menunjukkan bahwa dengan dilakukan penjelasan tentang manfaat air rebusan daun mint dan bagaimana cara meminumnya, maka dapat meningkatkan pengetahuan ibu tentang manfaat daun mint sebagai altarnetif untuk mengurangi mual muntah dan ibu dapat meminumnya saat mengalami mual muntah pada masa kehamilan.

\section{SIMPULAN}

Terdapat pengaruh pemberian air rebusan daun mint terhadap frekuensi mual dan muntah pada ibu hamil trimester 1 di klinik Pratama Jambu Mawar dengan nilai Pvalue $=0,000$ dengan demikian daun mint mampu mengurangi frekuensi mual muntah pada ibu hamil Trimester I.

\section{SARAN}

Disarankan bagi tenaga kesehatan dapat menjadikan hasil penelitian ini sebagai alternatif untuk mengatasi mual muntah pada ibu hamil. Bagi responden yaitu ibu hamil dapat mengaplikasikan rebusan daun mint untuk mengatasi mual muntah saat hamil.

\section{DAFTAR PUSTAKA}

Arumsari, K. (2019). Kadar Total Fenol, Aktivitas Antioksidan Dan Sifat Sensoris Teh Celup Campuran Bunga Kecombrang, Daun Mint Dan Daun Stevia. Naskah tidak dipublikasikan, Repository Universitas Muhamadyah Semarang, Yogyakarta 


\section{JKM (Jurnal Kebidanan Malahayati),Vol 7,No.3.Juli 2021, \\ ISSN (Print) 2476-8944 ISSN (Online) 2579-762X, Hal 523-527}

Afriyanti D. (2017). Efektivitas Wedang Jahe dan

Daun Mint Untuk Mengurangi Mual Muntah

Pada Ibu Hamil di PMB YF Kota Bukittinggi. Jurnal Human Care. E-ISSN:2528-66510, Volume 2, No 3.

Harahap HP, Oktafirnanda Y, Manggabarani S, (2020), Efektifitas The Daun Mint Terhadap Emesis Gravidarum Trmester I di Kelurahan Binjai Serbarangan Kecamatan Air Joman Kabupaten Asahan, Prosiding Seminar Nasional Multidisiplin IImu Universitas Asahan ke-4 Tahun 2020, Kisaran, 19 September 2020

Ira Puspito. (2012). 92 Pengobatan mandiri di rumah anda a-z gangguan kesehatan umum, cara mencegah dan cara mengatsainya. Yogyakarta: Bangkit.

Elshabrina. (2013). Dahsyatnya Daun Obat Sepanjang Masa. Yogyakarta: Cermelang Publishing.

Istiqomah (2017). Pengaruh Efektifitas Pemberian Seduhan Daun Pepermint Pada Ibu Hamil Terhadap Penurunan Frekuensi Emesis Gravidarum. Jurnal EDUMidwifery, Vol. 1, No.2 $103-107$

Mandriwati GA. (2018). Penuntun Belajar Asuhan Kebidanan Ibu hamil. Jakarta: EGC

Manuaba, I. A. C., Manuaba, I. B. G. F., \& Manuaba, I. B. G. (2015). IImu Kebidanan Penyakit Kandungan dan KB Untuk Pendidikan Bidan. EGC.

Parwitasari. (2014). Perbandingan Efektivitas Pemberian Rebusan Jahe Dan Daun Mint Terhadap Mual Muntah Pada Ibu
Hamil.Jurnal online mahasiswa, Volume 1 No 1.

Runjati, Umar S, dan Ester M. (2018). Kebidanan Teori dan Asuhan. Jakarta: EGC

Selina C, Darwis I, Graharti R (2019) Peppermint (Mentha Piperita) Sebagain pengobatan alternatif ada Irritable Bowel Syndrome (IBS), Majority, Volume 8, № 1, 211-219

Somoyani, N. K. (2018). Literature Review: Terapi Komplementer Untukmengurangi Mual Muntah Pada Masa Kehamilan. Jurnal IImiah kebidanan, 8 (1), 10-17.

Sugiono. (2012). Memahami Penelitian Kualitatif. Bandung : ALFABETA.

Suwarni. (2019). Hubungan Karakteristik Ibu Hamil Trimester I Dengan Morning Sickness di Poliklinik.

Tiran D. (2018). Mengatasi Mual-mual dan Gangguan Lain Selama Kehamilan. Jakarta: Disglossia

WHO. (2013). Reduction of Maternal Mortality. A Joint WHO/ UNFPA/ UNICEF/ world bank statement.

Widaryanti, R \& Riska. H, (2019). Terapi Komplementer Pelayanan Kebidanan Berdasarkan Bukti Scientific dan Empiris . CV Budi Utama. Yogyakarta.

Wulandari, D. A., Kustriyanti, D., \& Aisyah, R. (2019). Minuman Jahe Hangat Untuk Mengurangi Emesis Gravidarum Pada Ibu Hamil Di Puskesmas Nalumsari Jepara. Jurnal SMART Kebidanan, 6(1), 42. https://doi.org/10.34310/sjkb.v6i1.24 